\title{
Uterine Corpus Cancer pT2a TNM Finding v6
}

National Cancer Institute

\section{Source}

National Cancer Institute. Uterine Corpus CancerpT2a TNM Finding v6. NCI Thesaurus. Code C61347.

Uterine corpus cancer limited to the glandular epithelium of the endocervix. (from AJCC 6th Ed.) 